\title{
A case of multiple myeloma in a poultry worker
}

\author{
Pil Kyun Jung ${ }^{1,2}$, Inah Kim ${ }^{1,2,3,4,6^{*}}$, Inhyo Park ${ }^{4}$, Chinyon Kim², Eun-A Kim ${ }^{5}$ and Jaehoon Roh 2,3
}

\begin{abstract}
Background: Livestock breeders including poultry workers are exposed to various agricultural chemicals including pesticides and/or organic solvents. Multiple myeloma is a rare disease in Korea, and few reports have investigated the influence of occupational exposures on multiple myeloma occurrence.

Case presentation: A 61-year-old male poultry farm worker presented with bone pain and generalized weakness. A bone marrow biopsy was performed, and he was diagnosed with multiple myeloma. The patient had worked in a poultry farm for 16 years and was exposed to various pesticides and organic solvents such as formaldehyde without any proper personal protective equipment. Results of the work reenactment revealed that the concentration of formaldehyde (17.53 ppm) greatly exceeded the time-weighted average $(0.5 \mathrm{ppm})$ and short-term exposure limit (1.0 ppm) suggested in the Korean Industrial Safety and Health Act.

Conclusions: This case report suggests that poultry workers may be exposed to high levels of various hazardous chemicals including pesticides and/or organic solvents. Numerous previous studies have suggested an association between multiple myeloma and exposure to agricultural chemicals; thus, multiple myeloma in this patient might have resulted from the prolonged, high exposure to these chemicals.
\end{abstract}

Keywords: Poultry, Hematologic neoplasm, Multiple myeloma, Formaldehyde, Pesticides, Solvents

\section{Background}

Multiple myeloma is a type of hematological malignancy known to arise from post-germinal center plasma cells (B cells) [1]. Multiple myeloma accounts for approximately $1 \%$ of all types of malignancies and $10 \% 15 \%$ of hematological malignancies [2]. Epidemiologically, the median age at diagnosis is 66 years with a less than a $15 \%$ prevalence among those younger than $50[2,3]$. Multiple myeloma is also known to occur more frequently in males and blacks [2,4]. In Korea, multiple myeloma accounts for $0.5 \%$ of all types of malignancies and $12 \%$ of hematological malignancies [5]. The crude incidence rate (per 100,000 person-years) of multiple myeloma in Korea was found to have increased from 1999 (1.0) to 2011 (2.1) [5].

Patients who suffer from multiple myeloma present with symptoms or signs related to the infiltration of plasma cells into the relevant body organs or renal damage from excessive proteins [6]. Major symptoms or

\footnotetext{
* Correspondence: inahkim@yuhs.ac

${ }^{1}$ Graduate School of Public Health, Yonsei University, Seoul, Korea

${ }^{2}$ The Institute for Occupational Health, Yonsei University College of Medicine, Seoul, Korea

Full list of author information is available at the end of the article
}

signs at presentation are anemia, bone pain, elevated creatinine, generalized weakness, hypercalcemia, and/or weight loss [6]. A diagnosis of multiple myeloma is made when serum or urinary monoclonal protein and plasma cells in the bone marrow are present with accompanying end-organ damage [7]. Several epidemiological studies have suggested that occupational or environmental risk factors of multiple myeloma include ionizing radiation [8]; petrochemicals, and organic solvents such as benzene, heavy metals, asbestos, pesticides, and herbicides; however, the results are inconclusive $[9,10]$. Petrochemical, agricultural, wood, or printing workers as well as workers exposed to arsenic, lead, cutting oil, pesticides, or paints are believed to be at risk for developing multiple myeloma [11].

We present a case of multiple myeloma that occurred in a poultry farm worker who was exposed to pesticides and formaldehyde.

\section{Case presentation}

\section{Patient}

Sixty-one-year-old male.

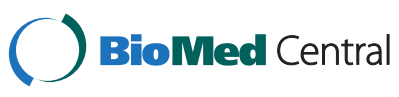

? 2014 Jung et al.; licensee BioMed Central Ltd. This is an Open Access article distributed under the terms of the Creative Commons Attribution License (http://creativecommons.org/licenses/by/4.0), which permits unrestricted use, distribution, and reproduction in any medium, provided the original work is properly credited. The Creative Commons Public Domain Dedication waiver (http://creativecommons.org/publicdomain/zero/1.0/) applies to the data made available in this article, unless otherwise stated. 


\section{Chief complaints}

Generalized weakness and bone pain.

\section{Past medical and family history}

No specific past medical or family history.

\section{Occupational history}

No specific occupational history.

\section{Present illness}

The patient initially presented with bone pain accompanied by generalized weakness. The result of the urinalysis indicated signs of a urinary tract infection. Treatment with antibiotics was attempted, but without improvement. Thereafter, he was admitted for acute renal failure. Bone marrow biopsy was also performed, and the patient was diagnosed with multiple myeloma (IgG, lambda type, CRAB $(-/+/+/+)$, ps1 iss3). Following the diagnosis, a hematologist started the patient on chemotherapy and hemodialysis.

\section{Occupational site and job description}

The patient was the sole operator of a poultry farm, established in 1996, that had three chicken sheds in operation from 1996 to 2005 and two from 2005. The measurement of each chicken shed was 10583 me-

ters with a maximum capacity of approximately 30,000 chickens. Aside from two air intake and exhaust ventilators, six ventilator fans are present on the sidewalls of each chicken shed. The air intake and exhaust systems are used during chicken rearing periods. After the chickens mature, they are shipped out of the sheds, and then a consecutive fumigation is performed (approximately 6 times/months). In order to maximize the fumigation effect, ventilators are only turned on after the fumigation is finished, regardless of whether a worker is present in the shed at the time of the fumigation.

The patients tasks at the poultry farm included the management and maintenance of consumable supplies and hygiene control, although his main tasks varied depending on the chicken rearing period. During the chickens growth period, the patients job was to spray pesticides containing dichlorovinyl dimethyl phosphate or ortho-dichlorobenzene on the floors using hand sprayers to maintain hygienic conditions in the sheds. In addition, the patient performed irregular weeding around the outside of the sheds using paraquat dichloride. After the mature chickens were shipped out of the sheds, the patient was responsible for fumigating the inside of the sheds using a diesel-fuel operated, manual, combustion fog machine. Thus, the patient was exposed to various chemicals during the fumigation, and other than cotton masks and cotton gloves, he wore no other personal protective equipment. The entire fumigation process from the inside wall to the entrance of the shed takes approximately one hour. Overall, five to six fumigations were performed in two months; thus, the average time spent on fumigations was approximately 18 hours per month between 1996 and 2005 when all three sheds were in operation and 12 hours per month from 2006 to 2011 when two sheds were in operation (Additional file 1: Table S1). Therefore, the estimated time spent fumigating was approximately 3,024 total hours over the course of the patients employment at the farm.

\section{Exposure assessment}

According to the materials safety data sheet, the fumigation chemicals used contain dichlorovinyl dimethyl phosphate, ortho-dichlorbenzene, cresol, methyl alcohol, benzalkonium chloride, high boiling tar acids, paraquat dichloride, sulphonic acid, chlorinated xylenols, and formaldehyde (Table 1). Previous measurements of chemicals used in the farm do not exist because the patient, who was the sole operator of the poultry farm, did not record this information.

Reenactment of the fumigation tasks were performed in January 2013 using personal samplers to estimate the levels of exposure to formaldehyde and organic solvents including benzene, which is an impurity sometimes present in pesticides (Figure 1). Samples were collected over the course of one hour. Eight-hour time weighted average exposure concentrations and the short-term exposure limit were calculated. The concentration of formaldehyde and benzene were estimated using NIOSH 2016 [12] and the 1501 methods [13]. Samples were analyzed using high-performance liquid chromatography for formaldehyde and gas chromatography with a flame ionization detector for benzene.

Table 1 Materials safety data sheet listing all products used in the poultry farm

\begin{tabular}{llcc}
\hline Product name & Constituent & CAS No. $^{*}$ & Percentage \\
\hline $\begin{array}{l}\text { Formaldehyde } \\
\text { 35\% }\end{array}$ & Formaldehyde 35\% & $50-00-0$ & 100 \\
DDVP & $\begin{array}{l}\text { Dichloro vinyl } \\
\text { dimethyl phosphate }\end{array}$ & $62-73-7$ & 90 \\
Olsozol & Ortho-dichlorbenzene & $95-50-1$ & $\mathrm{~N} / \mathrm{S}$ \\
& M-cresol & $108-39-4$ & $\mathrm{~N} / \mathrm{S}$ \\
& Methyl alcohol & $67-56-1$ & $\mathrm{~N} / \mathrm{S}$ \\
Gramoxone & Paraquat dichloride & $1910-42-5$ & 24 \\
inteon & & & Benzaikonium chloride \\
Baroclean & 264-151-6 & 50 \\
Longlife & High boiling tar acids & $84989-05-9$ & $15 \sim 30$ \\
& Chlorinated xylenols & Mixture & $\mathrm{N} / \mathrm{S}$ \\
& Sulphonic acid & $27176-870$ & $\mathrm{~N} / \mathrm{S}$ \\
\hline
\end{tabular}

"Chemical abstracts service number. Not specified. 


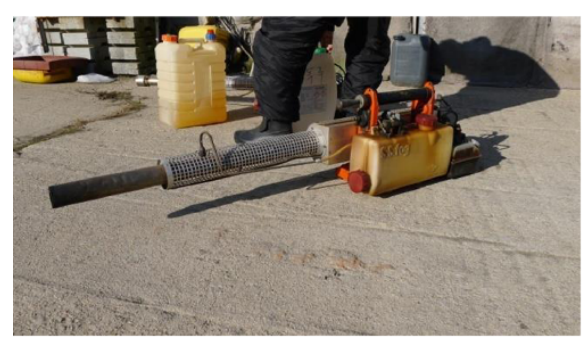

1. Preparing the combustion fog machine

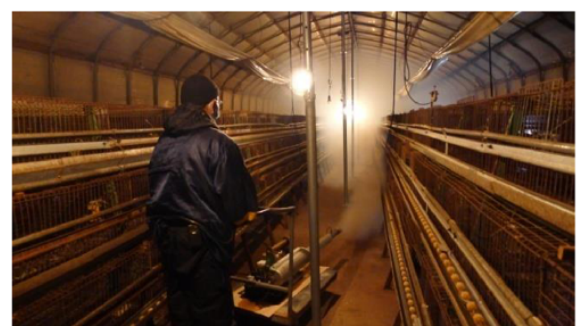

3. Fumigation task (1)

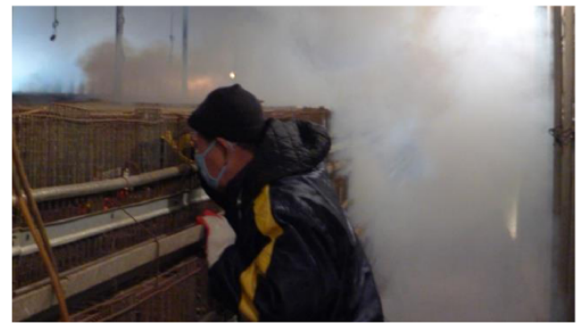

5. Fumigation task (3)

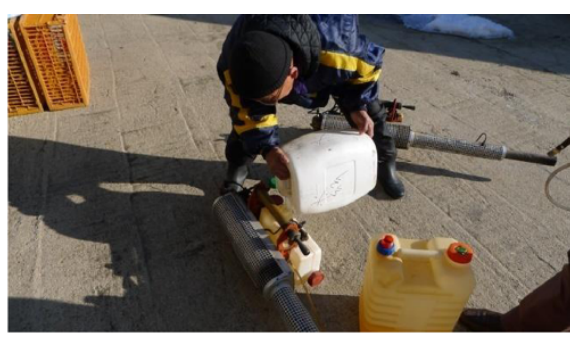

2. Supplying formaldehyde and pesticides

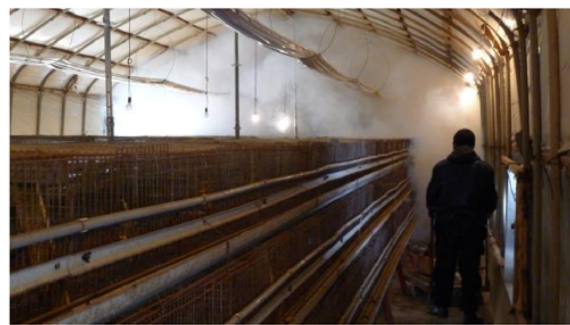

4. Fumigation task (2)

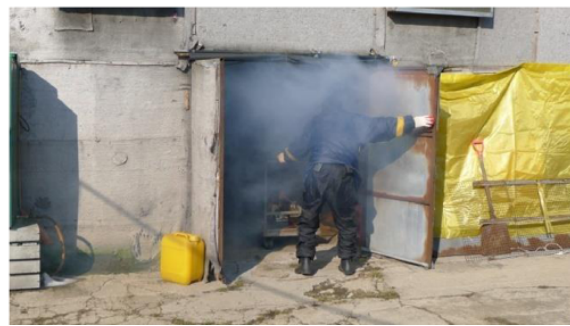

6. Fumigation task (4)

Figure 1 Reenactment of the fumigation procedure for exposure measurement.

The results of our analysis showed only small traces of benzene in the collected samples; however, our results may not be representative of the actual concentration of benzene in the pesticides used. The concentration of formaldehyde was estimated as $17.53 \mathrm{ppm}$, which greatly exceeds the time-weighted average and short-term exposure limit of $0.5 \mathrm{ppm}$ and $1.0 \mathrm{ppm}$, respectively, that are suggested in the Korean Industrial Safety and Health Act (Table 2) [14].

\section{Conclusions}

Agricultural chemicals used in the fumigation tasks, including pesticides and formaldehyde, are suspected to be

Table 2 Results of the exposure reenactment at the farm

\begin{tabular}{lllllll}
\hline $\begin{array}{l}\text { Organic } \\
\text { solvent }\end{array}$ & Method $^{*}$ & Time & & TWA & STEL & $\begin{array}{l}\text { Concentration } \\
\text { (ppm) }\end{array}$ \\
\hline Formaldehyde & Personal & $13: 30$ & $14: 30$ & 0.5 & 1 & 17.53 \\
Benzene & Personal & $13: 30$ & $14: 30$ & 1 & 5 & Trace \\
\hline
\end{tabular}

"Sampling method.

Sampling duration.

Time-weighted average suggested in the Korean Industrial Safety and Health Act.

Short-term exposure limit suggested in the Korean Industrial Safety and Health Act. the main occupational risk factors in the current case. In 2011, 1,050 and 218,017 new cases of multiple myeloma and all types of malignancies were diagnosed in Korea, respectively [5]. Because of the rare nature of this disease, studies on the risk factors of multiple myeloma have not been able to provide conclusive evidence of potential occupational risk factors.

Considering the widespread use of agricultural chemicals such as pesticides and/or fungicides, agricultural workers, especially livestock breeders, are known to be at a high risk factor of developing hematopoietic cancer $[15,16]$. Poultry workers and agricultural farmers both use a substantial amount of agricultural chemicals and organic solvents for hygiene control $[16,17]$.

The prevalence of multiple myeloma was higher among pesticide users than it was among other occupation groups according to the Agricultural Health Study (6.8\% v. $3.7 \%, \mathrm{OR}=1.9,95 \% \mathrm{CI}: 1.32 .7$ ) [18]. In a case control study conducted in Canada, the risk of multiple myeloma increased when patients were exposed to carbamates or captan class fungicides $(\mathrm{OR}=1.90,95 \% \mathrm{CI}$ : 1.11 3.27, 25 cases; OR $=2.35,95 \%$ CI: $1.03-5.35,14$ cases) [19]. In another case control study from 2000 to 
2004 in France that targeted 491 multiple myeloma patients from 6 hospitals, the risk of disease was highest among direct users of pesticides $(\mathrm{OR}=3.5,95 \% \mathrm{CI}$ : $1.67 .7,15$ cases) [20]. Several other studies have also suggested that the use of agricultural chemicals including various kinds of pesticides is related to an increased risk of multiple myeloma [21-23]. Working in the livestock breeding industry is also believed to be related to an increased risk of multiple myeloma especially if the livestock are sheep, cows, or pigs; however, we found no specific reports on poultry workers having an increased risk of multiple myeloma [15,21,24].

Among the different classes of agricultural chemicals, carbamates and organochlorides are known to be related to an increased risk of multiple myeloma [18,25]. Previous studies have not found a relationship between the occurrence of multiple myeloma and working with chickens $[21,24]$. Nevertheless, work environments can widely differ; therefore, the results of previous studies should be applied carefully [26].

Organic solvents such as benzene and formaldehyde, which our patient was exposed to, are both classified as group 1 carcinogens for hematopoietic cancer by the International Agency for Research on Cancer, and formaldehyde is a known risk factor for acute myeloblastic leukemia [27,28]. Formaldehyde has highly reactive properties and direct damage such as aberrations on peripheral blood cells or cytogenetic damage in bone marrow cells in animals have been observed [29]. After being absorbed into the body, most of the substance is converted into an oligomer in the form of a diol such as methanediol [30]. Since the molecular weights of oligomers are small enough to penetrate biological barriers [31], formaldehyde may also promote leukemogenesis by direct DNA damage and aneuploidy in hematopoietic stem or early progenitor cells [31-33].

Numerous previous studies have investigated the association between exposures to organic solvents and the occurrence of multiple myeloma. In a cohort study that included formaldehyde manufacturing factory workers, increased mortality was directly proportional to the peak exposure level, yet their results were not statistically significant (peak exposure $<2.0 \mathrm{ppm}$, relative risk $=1.0,11$ cases; peak exposure $2.0<4.0$ ppm relative risk $=1.65$, 13 cases, 95\% CI: 0.76 3.61, p trend >0.5; peak exposure $\geq 4.0 \mathrm{ppm}$, relative risk $=2.04,21$ cases, 95\% CI: 1.01 4.12, p trend >0.5) [34]. Studies targeting embalmers and the occurrence of other hematopoietic malignancies including myeloid leukemia also suggested heavily exposed groups were at a high risk $(\mathrm{OR}=3.9$, 95\% CI: 1.212 .5 among embalmers who worked $>34$ years) [27]. Few studies have investigated the influence of benzene exposure. However, one cohort study found an increased risk for hematopoietic cancers including multiple myeloma among workers exposed to unrefined petroleum chemicals containing benzene as an impurity [35,36].

The patient in the present study had worked at the same poultry farm for the last 16 years and was in charge of managing consumable supplies and hygiene control. To maintain the hygiene of the chicken sheds, the patient performed fumigations with pesticides and formaldehyde, and ventilator fans were turned off during the fumigation process to enhance the efficiency of the fumigation. This lack of ventilation has likely led to excessive exposures to hazardous chemicals. In the reenactment of the patients fumigation process, levels of exposure to formaldehyde and benzene greatly exceeded the time-weighted average and short-term exposure limit suggested in the Korean Industrial Safety and Health Act [14].

As the results of the exposure reenactment indicates, the patient was repeatedly exposed to an extremely high level of formaldehyde and other agricultural chemicals including pesticides. Until now, a clear association between pesticides or formaldehyde exposure and an increased risk of multiple myeloma remain inconclusive; however, our patients exposure to formaldehyde was exceptionally high, thus potential risks cannot be neglected. In addition, considering the frequency and prolonged duration of exposure to these hazardous chemicals, the patients circumstance could be considered extraordinary. The patient presented with no other known risk factors for multiple myeloma; however, due to a lack of education on occupational safety measures, the patient wore no personal protective equipment while working.

Although this study lacks enough epidemiological evidence to establish an association with multiple myeloma, the rare nature of the disease and extremely high level of exposure to hazardous chemicals over a prolonged time leads us to believe that the patients multiple myeloma likely originated after occupational exposure. Most poultry workers in Korea are considered petty; therefore, exposure to numerous health hazards is common, and they tend to receive no proper education on protective measures. In the future, improvements to work environments and educational programs on occupation hygiene are required. Moreover, the health effects of agricultural chemicals should be further evaluated. Last, large-scale prospective studies tracking the concentrations of compound chemicals used in agricultural work are required, and techniques to reduce their health effects should be developed.

\section{Consent}

Written informed consent was obtained from the patient for the publication of this report and all accompanying images. 


\section{Additional file}

Additional file 1: Table S1. Typical work schedule of the poultry farm.

\section{Competing interests}

The authors declared that they have no competing interests.

\section{Authors contributions}

PKJ: The first author of this article. He designed this research, collected and interpreted the data, conducted reproduction of relevant tasks, prepared the draft of this manuscript, and approved the final version of the manuscript. IK: The corresponding author of this article. She designed this research, collected and interpreted the data, conducted reproduction of relevant tasks, prepared the draft of this manuscript, and approved the final version of the manuscript. IP: He reviewed materials safety data sheet, assessed exposure status of workplace, conducted reproduction of relevant tasks, revised the draft of this manuscript, and approved the final version of the manuscript. CK: He reviewed materials safety data sheet, assessed exposure status of workplace, conducted reproduction of relevant tasks, revised the draft of this manuscript, and approved the final version of the manuscript. EAK: She revised the draft of this manuscript, and approved the final version of the manuscript. JR: He suggested the design of this research, interpreted results, revised the draft of this manuscript, and approved the final version of the manuscript.

\section{Acknowledgments}

This study was supported by the Occupational Safety and Health Research Institute (OSHRI), Korea Occupational Safety and Health Agency (KOSHA).

\section{Author details}

${ }^{1}$ Graduate School of Public Health, Yonsei University, Seoul, Korea. ${ }^{2}$ The Institute for Occupational Health, Yonsei University College of Medicine, Seoul, Korea. ${ }^{3}$ Department of Preventive Medicine and Public Health, Yonsei University College of Medicine, Seoul, Korea. ${ }^{4}$ Incheon Workers Health Center, Incheon, Korea. ${ }^{5}$ Occupational Safety and Health Research Institute, Korea Occupational Safety and Health Agency, Incheon, Korea. ${ }^{6}$ Severance Hospital, 50 Yonsei-ro, Seodaemun-gu, Seoul, Korea.

Received: 14 May 2014 Accepted: 14 October 2014

Published online: 01 November 2014

\section{References}

1. Kariyawasan CC, Hughes DA, Jayatillake MM, Mehta AB: Multiple myeloma: causes and consequences of delay in diagnosis. QJM 2007, 100:635 640 .

2. Siegel R, Ma J, Zou Z, Jemal A: Cancer statistics, 2014. CA Cancer J Clin 2014, 64:9 29.

3. Phekoo KJ, Schey SA, Richards MA, Bevan DH, Bell S, Gillett D, Moller H, Consultant Haematologists STHSC: A population study to define the incidence and survival of multiple myeloma in a National Health Service Region in UK. Br J Haematol 2004, 127:299 304.

4. Waxman AJ, Mink PJ, Devesa SS, Anderson WF, Weiss BM, Kristinsson SY, McGlynn KA, Landgren O: Racial disparities in incidence and outcome in multiple myeloma: a population-based study. Blood 2010, 116:5501 5506.

5. Annual report of cancer statistics in Korea in 2011. [http://ncc.re.kr/ english/infor/kccr.jsp]

6. Kyle RA, Gertz MA, Witzig TE, Lust JA, Lacy MQ, Dispenzieri A, Fonseca R, Rajkumar SV, Offord JR, Larson DR, Plevak ME, Therneau TM, Greipp PR: Review of 1027 patients with newly diagnosed multiple myeloma. Mayo Clin Proc 2003, 78:21 33.

7. Kyle RA, Greipp PR: Smoldering multiple myeloma. N Engl J Med 1980, 302:1347 1349.

8. Preston DL, Kusumi S, Tomonaga M, Izumi S, Ron E, Kuramoto A, Kamada N, Dohy H, Matsuo T, Matsui T: Cancer incidence in atomic bomb survivors. Part III. Leukemia, lymphoma and multiple myeloma, 19501987. Radiat Res 1994, 137:S68 S97.

9. Kyle RA, Rajkumar SV: Epidemiology of the plasma-cell disorders. Best Pract Res Clin Haematol 2007, 20:637 664.

10. Riedel DA, Pottern LM: The epidemiology of multiple myeloma. Hematol Oncol Clin North Am 1992, 6:225 247.
11. Ghosh S, McLaughlin JR, Spinelli JJ, Dosman JA, McDuffie HH, Pahwa P: Multiple myeloma and occupational exposures: a population-based case control study. J Occup Environ Med 2011, 53:641 646.

12. Formaldehyde 2016 - Centers for Disease Control and Prevention. [http://www.cdc.gov/niosh/docs/2003-154/pdfs/2016.pdf]

13. Hydrocarbons, aromatic 1501 - Centers for Disease Control and prevention. [http://www.cdc.gov/niosh/docs/2003-154/pdfs/1501.pdf]

14. Korean Industrial Safety and Health Act. [http://www.moleg.go. kr/english/korLawEng;jsessionid=CwcrBLHgCkVuHrVh1sY1R8r8Gv 7X4ifUiM1KYLKPNznwlkQreMFlpwxOhinquJwR.moleg_a2_servlet_engine2? pstSeq=57986\&pagelndex=4]

15. Eriksson M, Karlsson M: Occupational and other environmental factors and multiple myeloma: a population based case control study. Br J Ind Med 1992, 49:95 103.

16. Turner NW, Subrahmanyam S, Piletsky SA: Analytical methods for determination of mycotoxins: a review. Anal Chim Acta 2009, 632:168 180.

17. Hoppin JA, Umbach DM, London SJ, Alavanja MC, Sandler DP: Diesel exhaust, solvents, and other occupational exposures as risk factors for wheeze among farmers. Am J Respir Crit Care Med 2004, 169:1308 1313.

18. Landgren O, Kyle RA, Hoppin JA, Beane Freeman LE, Cerhan JR, Katzmann JA, Rajkumar SV, Alavanja MC: Pesticide exposure and risk of monoclonal gammopathy of undetermined significance in the Agricultural Health Study. Blood 2009, 113:6386 6391.

19. Pahwa P, Karunanayake CP, Dosman JA, Spinelli JJ, McDuffie HH, McLaughlin JR: Multiple myeloma and exposure to pesticides: a Canadian case control study. J Agromedicine 2012, 17:40 50.

20. Orsi L, Monnereau A, Dananche B, Berthou C, Fenaux P, Marit G, Soubeyran P, Huguet F, Milpied N, Leporrier M, Hemon D, Troussard X, Clavel J: Occupational exposure to organic solvents and lymphoid neoplasms in men: results of a French case control study. Occup Environ Med 2010, 67:664 672.

21. Freeman LEB, DeRoos AJ, Koutros S, Blair A, Ward MH, Alavanja M, Hoppin JA: Poultry and livestock exposure and cancer risk among farmers in the agricultural health study. Cancer Causes Control 2012, 23:663 670.

22. Khuder $S A$, Mutgi AB: Meta-analyses of multiple myeloma and farming. Am J Ind Med 1997, 32:510 516.

23. Viel JF, Richardson ST: Lymphoma, multiple myeloma and leukaemia among French farmers in relation to pesticide exposure. Soc Sci Med 1993, 37:771 777.

24. Baris D, Silverman DT, Brown LM, Swanson GM, Hayes RB, Schwartz AG, Liff JM, Schoenberg JB, Pottern LM, Greenberg RS, Stewart PA: Occupation, pesticide exposure and risk of multiple myeloma. Scand J Work Environ Health 2004, 30:215 222

25. Nanni O, Falcini F, Buiatti E, Bucchi L, Naldoni M, Serra P, Scarpi E, Saragoni $L$, Amadori D: Multiple myeloma and work in agriculture: results of a case control study in Forli, Italy. Cancer Causes Control 1998, 9:277 283.

26. Radon K, Danuser B, Iversen M, Monso E, Weber C, Hartung J, Donham K Palmgren U, Nowak D: Air contaminants in different European farming environments. Ann Agric Environ Med 2002, 9:41 48.

27. Hauptmann M, Stewart PA, Lubin JH, Beane Freeman LE, Hornung RW, Herrick RF, Hoover RN, Fraumeni JF Jr, Blair A, Hayes RB: Mortality from lymphohematopoietic malignancies and brain cancer among embalmers exposed to formaldehyde. J Natl Cancer Inst 2009, 101:1696 1708.

28. Coggon D, Harris EC, Poole J, Palmer KT: Extended follow-up of a cohort of british chemical workers exposed to formaldehyde. J Nat/ Cancer Inst 2003, 95:1608 1615 .

29. Heck H, Casanova M: The implausibility of leukemia induction by formaldehyde: a critical review of the biological evidence on distant-site toxicity. Regul Toxicol Pharmacol 2004, 40:92 106.

30. Gentry PR, Rodricks JV, Turnbull D, Bachand A, Van Landingham C, Shipp AM, Albertini RJ, Irons R: Formaldehyde exposure and leukemia: Critical review and reevaluation of the results from a study that is the focus for evidence of biological plausibility. Crit Rev Toxicol 2013, 43:661 670.

31. Speit G, Gelbke HP, Pallapies D, Morfeld P: Occupational exposure to formaldehyde, hematotoxicity and leukemia-specific chromosome changes in cultured myeloid progenitor cells. Cancer Epidemiol Biomarkers Prev 2010, 19:1882 1884. author reply 18841885.

32. Kuehner S, Schlaier M, Schwarz K, Speit G: Analysis of leukemia-specific aneuploidies in cultured myeloid progenitor cells in the absence and presence of formaldehyde exposure. Toxicol Sci 2012, 128:72 78.

33. Jakab MG, Klupp T, Besenyei K, Biro A, Major J, Tompa A: Formaldehydeinduced chromosomal aberrations and apoptosis in peripheral blood 
lymphocytes of personnel working in pathology departments. Mutat Res 2010, 698:11 17

34. Freeman LEB, Blair A, Lubin JH, Stewart PA, Hayes RB, Hoover RN, Hauptmann M: Mortality from lymphohematopoietic malignancies among workers in formaldehyde industries: the National Cancer Institute Cohort. J Natl Cancer Inst 2009, 101:751 761

35. Kirkeleit J, Riise T, Bratveit M, Moen BE: Increased risk of acute myelogenous leukemia and multiple myeloma in a historical cohort of upstream petroleum workers exposed to crude oil. Cancer Causes Control 2008, 19:13 23.

36. Infante PF: Benzene exposure and multiple myeloma: a detailed metaanalysis of benzene cohort studies. Ann N Y Acad Sci 2006, 1076:90 109.

doi:10.1186/s40557-014-0035-y

Cite this article as: Jung et al:: A case of multiple myeloma in a poultry worker. Annals of Occupational and Environmental Medicine 2014 26:35.

\section{Submit your next manuscript to BioMed Central and take full advantage of:}

$\otimes$ Convenient online submission

$\otimes$ Thorough peer review

$\nabla$ No space constraints or color $\nabla$ gure charges

$\otimes$ Immediate publication on acceptance

Q Inclusion in PubMed, CAS, Scopus and Google Scholar

$\otimes$ Research which is freely available for redistribution 